\title{
いぶしかわら製造法を用いたピラミッド型電磁波吸収体の作製とその特性
}

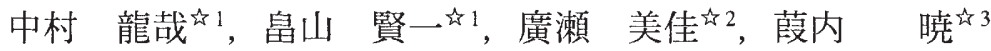

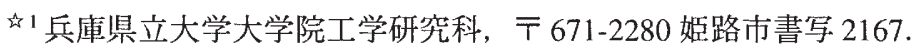 \\ 的松岡瓦産業検，广 679-2101 姫路市船津町 2039-1。 \\ 的3 東北化工㑣)，广 321-0532 那須鳥山市藤田 1200 .
}

\section{Preparation and Characterization of Pyramidal-shaped EM-wave Absorbers Produced by Smoked Roof-tile Process}

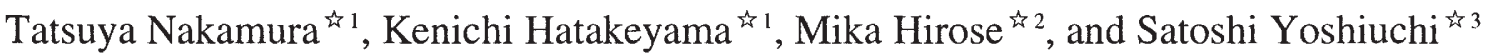 \\ 'Department of Eng., Graduate School of Eng., University of Hyogo, 2167 Shosha, Himeji 671-2280, Japan. \\ is 2Matsuoka Roofing Inc., 2039-1 Funatsu-cho, Himeji 679-2101, Japan. \\ ${ }^{3}$ Touhoku Chemical Industries, 1200 Fujita, Nasukarasuyama, Tochigi 321-0532, Japan.
}

Received January 23, 2009

\begin{abstract}
SYNOPSIS
EM-wave absorbers were prepared by a smoked roof-tile process. The shape of the absorbers was in pyramidal form, where the height was adjusted in the range of 100 to $200 \mathrm{~mm}$. The roof-tile process produced a carboncoated surface layer on the pyramidal-shaped substrate, which exhibited good electrical conductivity and led to good EM-wave absorption in the microwave frequency range. It is possible to adjust the center frequency of the absorption by changing the height of the pyramid. In addition, the absorbers exhibited strong resistance to highpower incident EM-waves, and the environmental stability in ambient atmosphere is expected.
\end{abstract}

\section{KEY WORDS}

EM-wave absorber, pyramidal-shaped absorber, smoked roof-tile process, carbon-coated surface layer

\section{1 緒言}

EMC対策のひとつである電磁波吸収体は, 古くから研究さ れており,なかでもウレタン等の発泡樹脂にカーボンを含浸 させたピラミッド型のものが, 軽量・高性能であることから 電波暗室などの用途に広く用いられている ${ }^{1.2}$. 電磁波吸収特 性は, 吸収体表面での入力インピーダンスと自由空間のイン ピーダンスを整合することによって達成されるものであり, 複素透磁率・複素誘電率などの材料性能だけでなく, 吸収体 の形状・厚さなども重要なファクターである32.

電磁波吸収体には, 電磁波吸収特性以外にその使用環境に 応じてさまざまな性能が要求される. 前述のカーボンを含浸 させたピラミッド型発泡樹脂吸収体は, 電波暗室等の屋内で 使用される限りにおいてはきわめて優秀なものであるが, 屋 外での使用には適していない. 屋外で長期間使用されると樹 脂が劣化し，結果的に電磁波吸収特性も劣化してしまう。ま た, 一方屋内での使用においても大電力の電磁波が照射され ると, 発熱によって極めて短時間の間に吸収体の温度が上昇 し，樹脂が変形・劣化を起こしてしまう。すなわち，カーボ
ン含浸ピラミッド型発泡樹脂吸収体は，十分な耐候性・耐電 力特性を有しているとはいいがたい.

ここでは, ETCシステムのような屋外環境でも使用可能で ある耐候性に加えて, かつ, 大電力の電磁波照射に対しても 十分な耐熱性を備えた電磁波吸収体の作製方法として, 日本 古来のセラミックスである瓦の製造方法のひとつであるいぶ し瓦製法を検討した. また，この方法で作製したピラミッド 型セラミックスを元に設計した電磁波吸収体の性能 (電磁波 吸収特性および耐電力特性) について研究したのでその結果 とあわせて報告する.

\section{2 試料の作製と実験方法}

プラスター枠の型枠をもちいて瓦粘土でピラミッド型成型 体 (壁厚み 5 から $10 \mathrm{~mm}$ )を作製し，これを室温にて十分に乾

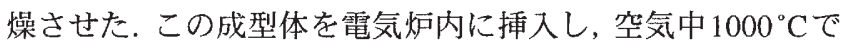
3時間焼成してピラミッド型のセラミックスを得た. その後, 密閉性のよい別の電気炉内に, このピラミッド型のセラミッ クスをその側面がガスとうまく接触するように互いに重なる 
ことがないように配置して, 窒素気流中で $1000^{\circ} \mathrm{C}$ まで加熱し た. 所定の温度に到達後, 窒素ガスを止代わりに一定流量 のブタンガスを流して煄化を開始した。 この燯化と同時に ヒ一ターによる加熱を止め, 自然冷却することで試料を作製 した.ここで，焼き上がりのピラミッドの高さが 10 から 20 $\mathrm{cm}$ となるように成型体の大きさを調整した. また, ピラミッ ドのアスペクト比 (高さと底面の一辺の長さの比) は約 1.5 と なるように設計した. ピラミッドの側面には放熱のために貫 通するように孔を設けたものも作製した。

得られたピラミッド型試料を複数個配列して 30 から $60 \mathrm{~cm}$ 四方の電磁波吸収体を構成し，これを金属板の上に配置して 電磁波吸収特性を測定した. 測定にはア一千型測定器を用い, 送受信アンテナとしてリッジガイドホーンアンテナ (Agilent Technology, 11966E) を使用し，入射・反射角度が $7^{\circ}$ となるよ うに設定し，周波数範囲 $3 \mathrm{GHz}$ から $11 \mathrm{GHz}$ で反射係数を測定 した.

\section{3 実験結果および考察}

空気中 $1000^{\circ} \mathrm{C}$ で焼成して得られたピラミッド型セラミック スは, Fig.1 (a)に示すように成型時に比べて収縮しているも のの刍裂等は見られず, 淡い茶褐色の均一な焼結体となって いることが認められた.この淡い茶褐色は粘土中に存在する 微量の鉄酸化物に由来するものである. 一方, このピラミッ ド型セラミックスをブタンガス中で加熱・燯化処理を施した ものの外観は Fig.1 (b) に示すように, 表面が金属光沢を有し た黒灰色を呈し，貫通するように孔を設けたものでは外側表 面だけでなく内側表面も均一に黒灰色の表面層で覆われてい ることが確認された.内側表面まで黒灰色層で覆われたのは, 放熱のために設けた側面の貫通孔を通ってガスが拡散したた めと思われる，破断面を観察した結果，この表面層の厚みは 比較的均一であり, 約 2 から $3 \mu \mathrm{m}$ であった．この表面層を同 定するためにラマン・スペクトルを測定した，その結果はピ ラミッド型セラミックスの場所によらずFig.2に示すように， $1350 \mathrm{~cm}^{-1}$ 付近と $1600 \mathrm{~cm}^{-1}$ 付近に大きなピークを持つカーボ

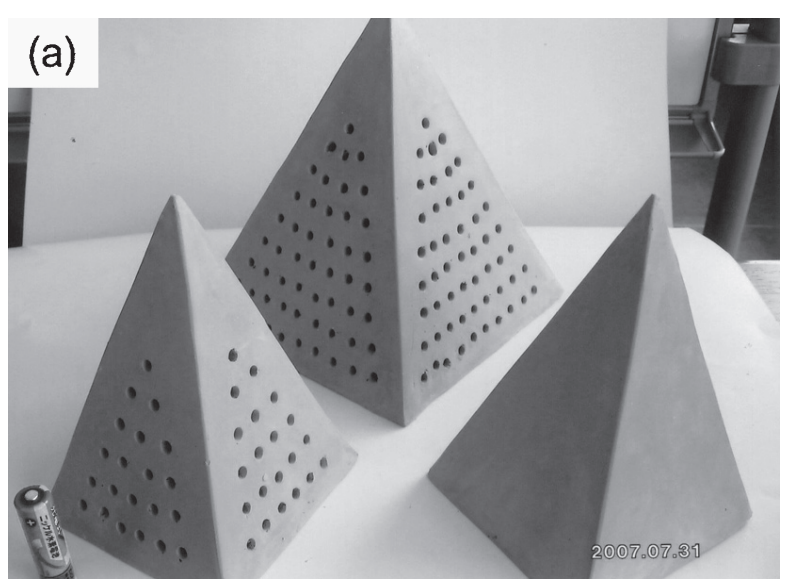

ンに特有のスペクトルであった，これは，炭化水素ガス(ブ タン) 中で加熱されることによって，炭化水素ガスの分解生 成物であるカーボンがセラミックス表面に沈着したものと考 えられる.この沈着した表面層はセラミックス基体と強固に 接合されており，このスペクトルからもわかるようにセラ ミックス基体に由来するシグナルがまったく見られないこと から，セラミックス表面全領域を覆っていることわかる(そ の厚みは 2 から $3 \mu \mathrm{m}$ 程度であった ). また, Fig.2に示したう マン・スペクトルを 4 本のシグナルに数值的に分解・評価し た.これらのうち, $1360 \mathrm{~cm}^{-1}$ と $1600 \mathrm{~cm}^{-1}$ にピークを持つ成 分はグラファイト類似の $\mathrm{sp}^{2}$-likeな局所構造に, $1210 \mathrm{~cm}^{-1}$ と $1530 \mathrm{~cm}^{-1}$ にピークを持つ成分は $\mathrm{sp}^{3}$-likeな局所構造に由来す るものである ${ }^{4-6)}$.グラフからわかるように, グラファイト由 来の成分が $60 \%$ 程度存在し, セラミックス表面に十分な電気 伝導性が付与されていることが期待された. そこで四端子法 をもちいて，セラミックス表面の面抵抗を測定したところ， 約 $70 \Omega$ であり十分な導電性を有していることがわかった.こ れらの結果, ピラミッド型セラミックスをブタンガス中で加 熱・燯化処理を施すことにより，その表面に電気伝導性を有

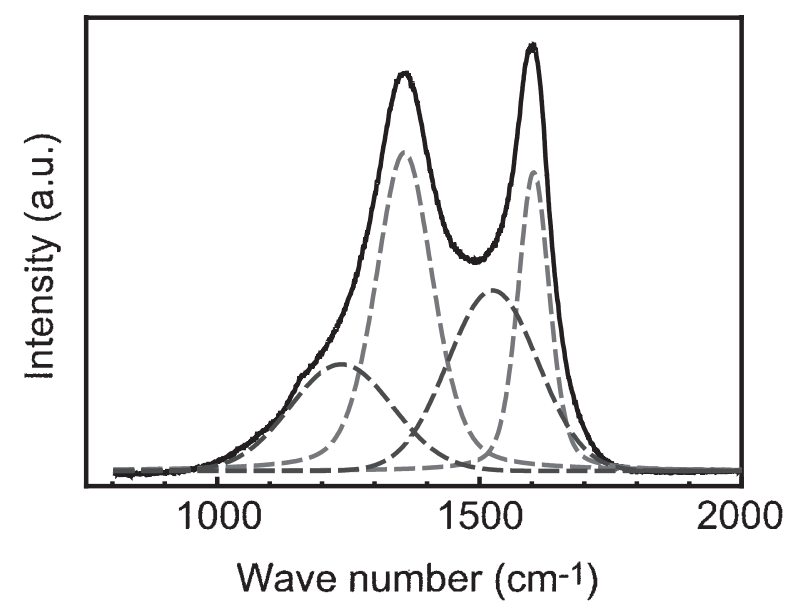

Fig.2 Raman spectrum for the surface of the ceramics produced by the smoked roof-tile process.

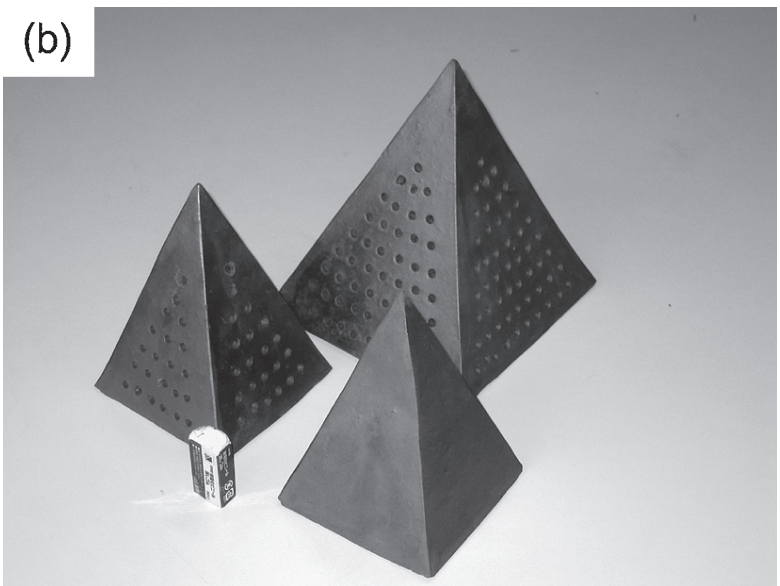

Fig.1 Pictures of pyramidal shaped ceramics (a) before and (b) after the smoked roof-tile treatment. 
したカーボン皮膜を沈着させることができ，このピラミッド の形状・大きさを制御することで電磁波吸収体用の材料とな りうることがわかった。

Fig.3およびFig.4に, 得られたピラミッド型試料から構成 した電磁波吸収体の吸収特性を示す。これらの図中には, カーボンを含浸させたピラミッド型発泡樹脂吸収体の特性も 合わせて示した ${ }^{2.7)}$. 反射係数が $-20 \mathrm{~dB}$ 以下になると反射波 は入射波の $1 \%$ 以下になることから，-20 dB以下の周波数領 域を吸収帯域と考えるものとする. 従来から検討されている カーボンを含浸させたピラミッド型発泡樹脂吸収体の吸収ス ペクトルを見ると, ピラミッドの高さが高いものほど吸収が 低い周波数から始まり高い周波数になるほど良好な吸収を示 すことがわかる.これは電磁波の波長とピラミッドの高さの 比で吸収特性が統一的に議論できることを意味しているもの である.このカーボンを含漫させたピラミッド型発泡樹脂吸 収体の場合，ピラミッドの高さが $20 \mathrm{~cm}$ のものでは $500 \mathrm{MHz}$ 以上の周波数で, ピラミッドの高さが $10 \mathrm{~cm}$ ののでは $1 \mathrm{GHz}$ 以上の周波数で, $-20 \mathrm{~dB}$ 以下の吸収を示し良好な電磁波吸収 体として動作することがわかる.

これら従来のピラミッド型電磁波吸収体と今回設計した新 しいタイプのピラミッド型電磁波吸収体を比較する. 開発し たいぶし瓦製造法をもちいたピラミッド型電磁波吸収体の吸 収スペクトルは，ピラミッドの高さが $20 \mathrm{~cm}$ のものは中心周 波数 $4 \mathrm{GHz}, 3 \mathrm{GHz}$ から $8 \mathrm{GHz}$ の周波数域で $-20 \mathrm{~dB}$ 以下の吸 収を示し，ピラミッドの高さが $10 \mathrm{~cm}$ の場合では中心周波数 $9 \mathrm{GHz}, 3 \mathrm{GHz}$ から $12 \mathrm{GHz}$ の周波数域で-20 dB 以下の吸収を 有していることがわかった.ピラミッドの高さが高くなるほ ど, 吸収の周波数帯域が低周波数側へずれることに関しては, 従来のカーボンを含浸させたピラミッド型発泡樹脂吸収体の 場合と同様の傾向である，ところが，吸収スペクトルの様子 は従来のカーボンを含浸させたピラミッド型発泡樹脂吸収体

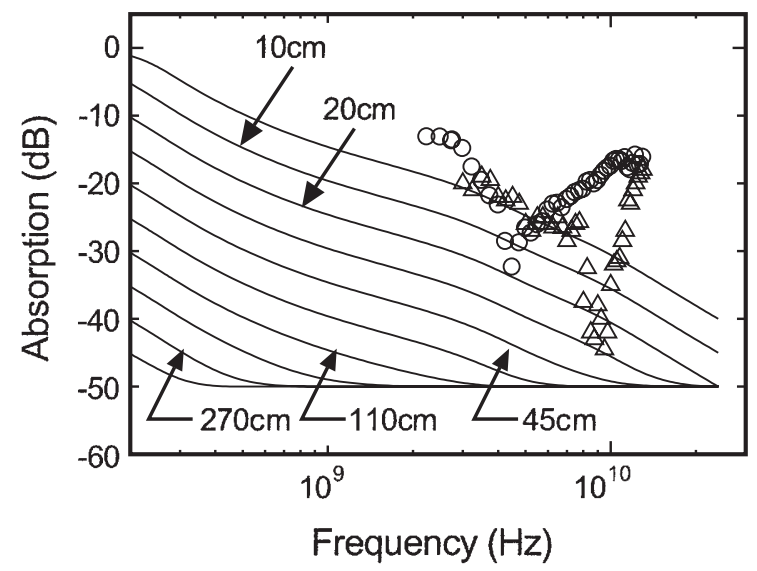

Fig.3 EM-wave absorption versus frequency on a logarithmic scale: the circles and triangles denote the absorption data of the pyramid with the height of 20 and $10 \mathrm{~cm}$, respectively. The solid lines denote the absorption spectra of the urethane pyramidal absorbers with various heights.
のものと比べると大きく異なり, むしろ酸化物磁性体である フェライトを用いた電磁波吸収体のスペクトル とよく似て いる. すなわち, ある周波数で最大の吸収を示し，その周波 数以上では吸收特性が低下することがわかった。これは，ピ ラミッド表面の面抵抗の最適化をすることで改善できるもの と思われ，表面のカーボン層の構造・厚みなどをさらに検討 することが今後の課題である.

このように，いぶし瓦製法を応用して作製したピラミッド 型電磁波吸収体は, 高周波帯域での吸収特性は従来のカーボ ンを含浸させたピラミッド型発泡樹脂吸収体のものと比べ劣 るものの, その材質・製造方法を考えると, 瓦同様に優れた 耐候性を備えており, 従来のカーボンを含浸させたピラミッ ド型発泡樹脂吸収体で問題となる屋外環境でも使用可能であ ることが十分に期待できる. 従来のピラミッド型発泡樹脂吸 収体のもうひとつの問題が大電力の電磁波照射時における耐 熱性である.そこで，いぶし瓦製法を応用して作製したピラ ミッド型電磁波吸収体の耐熱性・耐電力性について以下のよ うな手法で試験を行った. 高さが $10 \mathrm{~cm}$ のピラミッド型電磁 波吸収体(周波数 $2.45 \mathrm{GHz}$ における吸収は-16 dBである)に, 周波数 $2.45 \mathrm{GHz}$, 単位面積あたりの照射エネルギーが $18 \mathrm{~kW} / \mathrm{m}^{2}$ となるように出力を調整した電磁波を照射した．実際には, 入射電力, 反射電力を方向性結合器に接合させてメーターに て計測し. 反射電力がなくなり入射電力がすべて試料に吸収 されるように調整した. ピラミッドの先端付近の温度が最も 高くなると思われるが，ここではピラミッド先端から約 $3 \mathrm{~cm}$ だけ下がった位置でのピラミッド表面の温度を光ファイバー 温度計を用いて計测した.このときの電磁波の照射時間とピ ラミッド表面の温度の関係をFig.5に示した. 同様の実験を従 来のピラミッド型発泡樹脂吸収体に対しておこなったところ, わずか数分で表面温度が $200^{\circ} \mathrm{C}$ 以上まで上昇するとともに, ピラミッドの外形が大きく変形してしまい, 酎熱性・耐電力

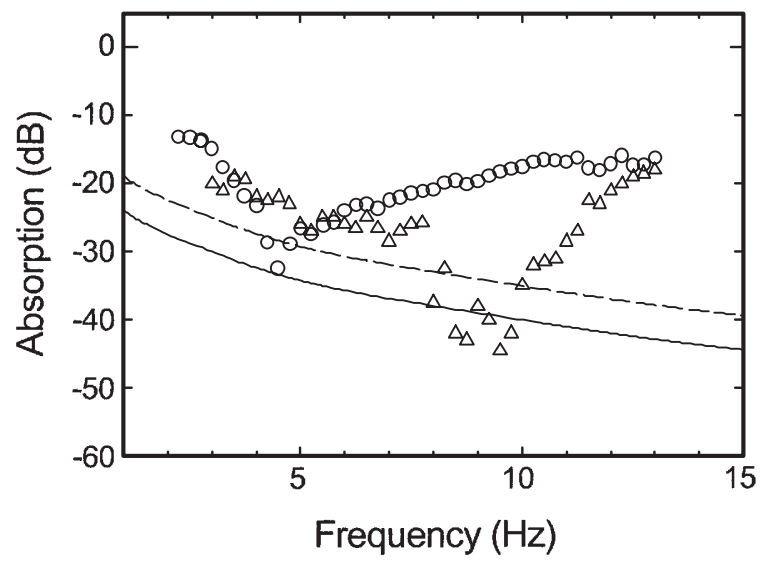

Fig.4 EM-wave absorption spectra, where the frequency is on a linear scale. The circles and triangles denote the absorption for the pyramids with heights of 20 and $10 \mathrm{~cm}$, respectively. The dashed and solid lines denote the absorption spectra of the urethane pyramidal absorbers with heights of 10 and 20 $\mathrm{cm}$, respectively. 


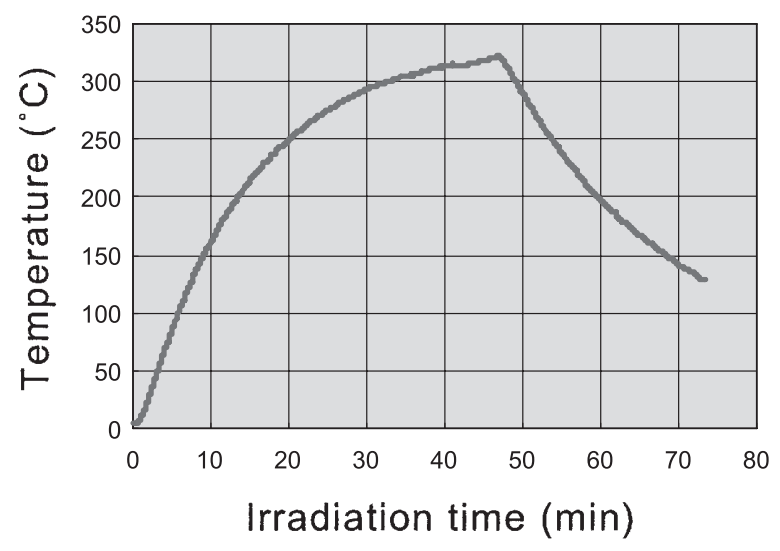

Fig.5 Temperature profile of the absorber surface during microwave irradiation: frequency of $2.45 \mathrm{GHz}$ and incident energy of $18 \mathrm{~kW} / \mathrm{m}^{2}$.

性が大きな問題であることを再確認した。一方, 開発した新 しいタイプの電磁波吸収体では, 照射開始から約 45 分でピラ ミッドの表面温度は $320^{\circ} \mathrm{C}$ に到達し, 飽和する傾向を呈して いた. その後, 照射を停止すると緩やかに温度は下降した.十 分に冷却した後に, このピラミッド型電磁波吸収体を検查し たところ，照射前と外観からも目立った変化は認められな かった.すなわち, このピラミッド型電磁波吸収体は, $300^{\circ} \mathrm{C}$ 程度までの温度上昇であれば十分に耐熱性を有しており, 変 質・変形などの発生はなく, かつ表面カーボン膜の導電性に もまったく影響がない，電磁波吸收特性にも変化がないこと が明らかとなった。

\section{4 まとめ}

日本古来のセラミックスである瓦の製造方法のひとつであ るいぶし瓦製法を用いてピラミッド型セラミックスを作製し， これを元に電磁波吸収体を設計した。 その結果，以下のこと が明らかとなった。

(1) ブタンガスを高温で熱分解することで, セラミックス表 面に導電性のカーボン膜を形成でき, しかもこの膜は下 地と強固に接合している.

(2) ピラミッド形状とすることで, 前述の導電性表面カーボ ン膜を利用した電磁波吸収体が設計できる. その動作周 波数は数 $\mathrm{GHz}$ を中としたものである.
（3）その材質・製造方法に由来して，この電磁波吸収体は屋外 環境での使用にも耐えうる十分な耐候性を有し，かつ大 電力照射時においても $300^{\circ} \mathrm{C}$ 程度までの温度に対する耐 熱性・耐電力性を備えている.

（4）ある周波数で最大の吸収を示し，その周波数以上では吸 収特性が低下することが課題として残された，これを改 善するためには, ピラミッド表面の面抵抗の最適化を検 討することが必要である.

\section{謝辞}

本研究は, 総務省平成 19-20 年度戦略的情報通信研究開発 推進制度 (SCOPE), 地域ICT振興型開発研究の受託研究とし て実施したものである. 関係各位に梁く感謝する.

\section{文献}

1) W.H. Emerson, A.G. Sands, and M.V. McDowell: "Development of Broadband Absorbing Materials for Frequencies as low as 500MC", Naval Research Laboratory Memorandum Report, (1954).

2) W.H. Emerson: "Electromagnetic wave absorbers and anechoic chambers through the years", IEEE Trans. Antennas Propag., AP-21(1973)484-489.

3) Y. Shimidzu, et al.: "Electromagnetic wave absorbing and shielding", Nikkei-gijyutsu, (1999) 85.

4) M.M. Doeff, Y. Hu, F. McLarnon, and R. Kostecki: "Effect of Surface Carbon Structure on the Electrochemical Performance of $\mathrm{LiFePO}_{4}$ ", Electrochem. Solid-State Lett., 6(2003)A207-A209.

5) Y. Hu, M.M. Doeff, R. Kostecki, and R. Finones: "Electrochemical Performance of Sol-Gel Synthesized $\mathrm{LiFePO}_{4}$ in Lithium Batteries", J. Electrochem. Soc., 151(2004)A1279A1285.

6) T. Nakamura, Y. Miwa, M. Tabuchi, and Y. Yamada: "Structural and surface modifications of $\mathrm{LiFePO}_{4}$ olivine particles and their electrochemical properties", J. Electrochem. Soc., 153(2006) A1108-A1114.

7) Emerson and Cuming Inc.: Technical Bulletin 8-12-8, (1979).

8) Y. Naito and K. Suetake: "Application of Ferrite to Electromagnetic Wave Absorber and Its Characteristics", IEEE Trans. Microwave Tech. Tech., MTT-1(1971)65-72. 